Check for updates

Cite this: Phys. Chem. Chem. Phys., 2018, 20, 8143

Received 18th January 2018, Accepted 27th February 2018 DOI: $10.1039 / c 8 c p 00399 h$

rsc.li/pccp

\section{Photochemistry of glyoxylate embedded in sodium chloride clusters, a laboratory model for tropospheric sea-salt aerosols $\dagger$}

\author{
Nina K. Bersenkowitsch, Milan Ončák, (D)* Christian van der Linde, (D) \\ Andreas Herburger and Martin K. Beyer (D)*
}

Although marine aerosols undergo extensive photochemical processing in the troposphere, a molecular level understanding of the elementary steps involved in these complex reaction sequences is still missing. As a defined laboratory model system, the photodissociation of sea salt clusters doped with glyoxylate, $\left[\mathrm{Na}_{n} \mathrm{Cl}_{n-2}\left(\mathrm{C}_{2} \mathrm{HO}_{3}\right)\right]^{+}, n=5-11$, is studied by a combination of mass spectrometry, laser spectroscopy and ab initio calculations. Glyoxylate acts as a chromophore, absorbing light below $400 \mathrm{~nm}$ via two absorption bands centered at about 346 and $231 \mathrm{~nm}$. Cluster fragmentation dominates, which corresponds to internal conversion of the excited state energy into vibrational modes of the electronic ground state and subsequent unimolecular dissociation. Photochemical dissociation pathways in electronically excited states include $\mathrm{CO}$ and $\mathrm{HCO}$ elimination, leading to $\left[\mathrm{Na}_{n-x} \mathrm{Cl}_{n-x-2} \mathrm{HCOO}^{+}\right.$and $\left[\mathrm{Na}_{n} \mathrm{Cl}_{n-2} \mathrm{COO}\right]^{+}$with typical quantum yields in the range of $1-3 \%$ and $5-10 \%$, respectively, for $n=5$. The latter species contains $\mathrm{CO}_{2}{ }^{--}$stabilized by the salt environment. The comparison of different cluster sizes shows that the fragments containing a carbon dioxide radical anion appear in a broad spectral region of 310-380 $\mathrm{nm}$. This suggests that the elusive $\mathrm{CO}_{2}{ }^{--}$species may be formed by natural processes in the troposphere. Based on the photochemical cross sections obtained here, the photolysis lifetime of glyoxylate in a dry marine aerosol is estimated as 10 h. Quantum chemical calculations show that dissociation along the $\mathrm{C}-\mathrm{C}$ bond in glyoxylic acid as well as glyoxylate embedded in the salt cluster occurs after reaching the $\mathrm{S}_{1} / \mathrm{S}_{0}$ conical intersection, while this conical intersection is absent in free glyoxylate ions.

\section{Introduction}

Marine aerosols ${ }^{1-4}$ are composed of a complex mixture of inorganic as well as organic components. Besides sodium chloride and water as the main constituents, hydrocarbons such as lipids, acids, humic substances, and saccharides play an essential role in the chemistry of marine aerosols. ${ }^{3,5-8}$ Sea spray aerosols are produced by the mechanical disruption of the ocean surface, ${ }^{9}$ with the size of the released droplets depending strongly on the wind speed. ${ }^{10,11}$ Gas to particle conversion processes like nucleation and condensation form secondary sea salt aerosols including organic as well as nonorganic constituents, e.g. sulphate. ${ }^{12}$

As the ocean covers more than $70 \%$ of the Earth's surface, this type of natural aerosol is highly relevant for atmospheric processes.

Institut für Ionenphysik und Angewandte Physik, Universität Innsbruck, Technikerstraße 25, 6020 Innsbruck, Austria. E-mail: milan.oncak@uibk.ac.at, martin.beyer@uibk.ac.at

$\dagger$ Electronic supplementary information (ESI) available. See DOI: 10.1039/ c8cp00399h
The complexity of these processes is a challenge for numerical climate models. ${ }^{13,14}$ Aerosols provide condensation nuclei for cloud droplets and sea salt particles cannot only backscatter, ${ }^{2}$ but also absorb solar radiation. ${ }^{15,16}$ Sea-salt aerosols exhibit a rich chemistry with atmospheric trace gases ${ }^{17}$ and complex photochemical reactions. ${ }^{18,19}$ Photochemical processing of organic matter ${ }^{9,19,20}$ is initiated by sunlight, and highly reactive species such as $\mathrm{OH}^{\bullet}$ can be produced. ${ }^{21,22}$

Gas-phase sodium chloride clusters ${ }^{23}$ are well-established model systems for salt surfaces. ${ }^{24}$ In the present study, sodium chloride is used as a basis for modeling photochemical reactions on salt clusters. The clusters are doped with glyoxylic acid, ${ }^{25-27}$ one of the most abundant 2-oxocarboxylic acids ${ }^{25}$ in organic aerosols in environments like the North China Plain ${ }^{28}$ or marine regions ${ }^{29,30}$ such as the eastern North Pacific. The neutral molecule absorbs in the actinic region with $\lambda>290 \mathrm{~nm}$, the wavelength range of solar radiation that reaches the troposphere. ${ }^{26}$ Since in aqueous solution at neutral $\mathrm{pH}$ the gem-diol form $\mathrm{HC}(\mathrm{OH})_{2} \mathrm{COO}^{-}$dominates, ${ }^{31}$ we cannot rule out that glyoxylate in wet sea-salt aerosols may also be present as gem-diol. Our study using dry $\mathrm{HCOCOO}^{-}$thus represents only the first step 
towards a comprehensive understanding of glyoxylate photochemistry in this environment.

In the gas phase, the major products of glyoxylic acid photodissociation as well as its thermal decomposition are $\mathrm{CO}_{2}$ and $\mathrm{CH}_{2} \mathrm{O}$, with minor contributions of $\mathrm{CO}$ and $\mathrm{H}_{2} \cdot{ }^{26}$ Quantum chemical calculations suggested high barriers for the lowest energy unimolecular decomposition pathway, in the range of $200 \mathrm{~kJ} \mathrm{~mol}^{-1}$. $^{32}$ Hydration with a single water molecule leads to an only mild reduction of the barrier for $\mathrm{H}_{2}$ formation, from $214 \mathrm{~kJ} \mathrm{~mol}^{-1}$ to $181 \mathrm{~kJ} \mathrm{~mol}^{-1}$. ${ }^{33}$ Under experimental conditions in the gas or liquid phase, however, bimolecular collisions may be involved, enabling additional reaction pathways. Vaida and co-workers showed by vibrational spectroscopy that glyoxylic acid is also present in its geminal diol form. ${ }^{34}$ They also showed that vibrational overtone excitation of the $\mathrm{O}-\mathrm{H}$ mode with four or five vibrational quanta leads to decomposition of glyoxylic acid if the hydrogen atom is oriented to form an intramolecular hydrogen bond. ${ }^{35}$ The isomerization reactions involved in formation of this intramolecular hydrogen bond can be induced by near-infrared light, as shown in argon matrices by Olbert-Majkut et al. ${ }^{36}$ In aqueous solution, Guzman and co-workers identified a number of photolysis products, including $\mathrm{CO}_{2}, \mathrm{CO}$, formic acid, oxalic acid, and tartaric acid. ${ }^{25}$ They propose the homolytic cleavage of the $\mathrm{C}-\mathrm{C}$ bond as the first step in the reaction cascade, followed by a series of bimolecular reactions. Related studies can be found for pyruvic acid. ${ }^{37-39}$

Photocatalytic oxidation of glyoxylate adsorbed on quantumsized ZnO was observed by Hoffmann and co-workers. ${ }^{40}$ Ekström and McQuillan reported the coordination of glyoxylate on $\mathrm{TiO}_{2}$ in aqueous solution in its hydrated form, and the formation of adsorbed oxalate upon near-UV irradiation. ${ }^{41}$ In the gas-solid system, glyoxylate is adsorbed in several ways on $\mathrm{TiO}_{2}$, reported by Ho et al. ${ }^{42}$ Thermal decomposition results in $\mathrm{CO}, \mathrm{CO}_{2}$, adsorbed formate and methoxy groups, while photodissociation at $350-450 \mathrm{~nm}$ leads to $\mathrm{CO}_{2}$, carbonate and formate. All these surface studies are interpreted in terms of photocatalytic activity of the support, while direct photolysis of e.g. the $\mathrm{C}-\mathrm{C}$ bond in glyoxylate was not considered.

Here we address the photochemistry of cationic sodium chloride clusters doped with a glyoxylate anion. Photodissociation cross sections are measured, and the photodissociation products are identified by mass spectrometry. Quantum chemical calculations of ground and first excited state provide a molecular level understanding of the observed photodissociation pathways. Comparison of the situation of the ion embedded in the cluster with the bare ion as well as the neutral molecule in the gas phase reveals the influence of the ionic environment.

\section{Experimental and theoretical details}

The experimental setup consists of a Bruker Apex Qe Fourier transform ion cyclotron resonance (FT-ICR) mass spectrometer interfaced to a tunable optical parametric oscillator (EKSPLA NT342B) as described in detail before. ${ }^{43}$ Briefly, cluster ions
$\mathrm{Na}_{n+1} \mathrm{Cl}_{n-1}\left(\mathrm{C}_{2} \mathrm{HO}_{3}\right)^{+}$are generated by electrospray ionization and transferred to a hexapole collision cell where they are thermalized in collisions with argon at room temperature. After injection into the ICR cell, the ion of interest is mass selected by resonant excitation of unwanted ions.

Tunable laser light is allowed into the ICR cell for a defined period of time controlled by a mechanical shutter. Due to the long irradiation times of up to $20 \mathrm{~s}$ used in the present study, also very weak photodissociation cross sections can be determined quantitatively. For the calculation of the total photodissociation cross section, also the fragmentation occurring due to black body infrared radiation dissociation (BIRD) $)^{44}$ has to be taken into account, eqn (1).

$$
\sigma_{\mathrm{tot}}=\frac{h c A}{\lambda p E}\left(\ln \frac{\sum_{i=0}^{n} I_{i}}{I_{0}}-k_{\mathrm{BIRD}} t_{\mathrm{irr}}\right)
$$

$I_{0}$ represents the intensity of the precursor ion after laser irradiation, $I_{i}$ the corresponding intensities of fragment $i, h$ Planck's constant, $c$ the speed of light, $A$ the area illuminated by the laser beam, $\lambda$ the wavelength, $p$ the number of laser pulses, $E$ the energy of a laser pulse, $t_{\text {irr }}$ the irradiation time of the precursor ion and $k_{\text {BIRD }}$ the rate constant for BIRD. This quantity can be measured independently via eqn (2) where the precursor ion is stored for different times and exposed to the room temperature blackbody radiation. Since the dissociation due to BIRD follows an exponential law, the fit gives the rate constant $k_{\mathrm{BIRD}}$.

$$
I_{0}(t)=I_{0} \mathrm{e}^{-k_{\text {BIRD }} t_{\text {irr }}}
$$

Partial cross sections of the individual fragments $\sigma_{i}$ are calculated via eqn (3):

$$
\sigma_{i}=\frac{I_{i, i}-I_{0, i}}{\sum_{i=1}^{n} I_{i, i}-\sum_{i=1}^{n} I_{0, i}} \sigma_{\text {tot }}
$$

where $I_{i, i}$ is the intensity of the fragment after irradiation of the precursor ion with UV light and $I_{0, i}$ the intensity of the fragment contribution due to BIRD.

The main sources of error of the absolute cross section are the measured rate constant $k_{\mathrm{BIRD}}$ and the photon flux inside the ICR cell. A peak at $\Delta m / z=0.17$ was present in small amounts in most experiments, which was too close to be ejected without exciting the ion of interest. This peak was assigned, and for stoichiometric reasons its photofragments do not interfere with the major photofragments of the ion of interest, see Fig. S1 (ESI $\dagger$ ).

Pulse energies in UV fluctuate significantly since UV photons are generated in four stages of non-linear optics in the OPO system. Together with uncertainties in the alignment of the laser beam and beam profile in the ICR cell, located at a distance of $3 \mathrm{~m}$ from the laser system, the absolute cross sections reported here are estimated to be accurate within 30\%.

All chemicals were purchased from Sigma Aldrich with a purity of at least $98 \%$. Isotopically enriched $\mathrm{Na}^{35} \mathrm{Cl}$ is used for the studies, as mass spectra become significantly complicated with increasing cluster size due to the two stable isotopes of $\mathrm{Cl}$. 
In all measurements, a 1:1 mixture of $\mathrm{CH}_{3} \mathrm{OH} / \mathrm{H}_{2} \mathrm{O}$ (HPLC grade) was used as solvent. The measurements were performed with a $\mathrm{NaCl}$ concentration of $5 \mathrm{mmol} \mathrm{L}^{-1}$ and $1 \mathrm{mmol} \mathrm{L}^{-1}$ glyoxylic acid.

Structure and photochemistry of the clusters were also explored using methods of theoretical chemistry. Initial structures were taken from the Cambridge Cluster Database ${ }^{45}$ for $\left[\mathrm{Na}_{n} \mathrm{Cl}_{n+1}\right]^{-}$clusters and modified to $\left[\mathrm{Na}_{n+1} \mathrm{Cl}_{n}\right]^{+}$. For each cluster size and for each position of the $\mathrm{Cl}^{-}$ion, we replaced the $\mathrm{Cl}^{-}$ion by the $\mathrm{C}_{2} \mathrm{HO}_{3}{ }^{-}$anion and optimized the cluster at the respective level of theory. For $n=5$, further isomers with different $\mathrm{O}-\mathrm{C}-\mathrm{C}-\mathrm{O}$ dihedral angle were created starting from the respective minima. Several structures were also created by incorporating the ion into the cluster or on its surface. Initial structures for clusters after glyoxylate dissociation were built from the optimized clusters. Cluster optimization was performed at the B3LYP/def2TZVP and B3LYP/6-31+g* level of theory for smaller and larger systems, respectively, with the dispersion correction (D2) as introduced by Grimme. ${ }^{46}$ We note that this correction changes both the relative stability of clusters and their structure (see Table S1, ESI $\dagger$ ).

Excited states of clusters were calculated at the EOM-CCSD level. The TDDFT method with two tested hybrid functionals, BHandHLYP and CAM-B3LYP, predicted artificial charge transfer states when $\mathrm{Cl}^{-}$ions were present in the cluster (see Table S2 and the corresponding discussion, ESI $\dagger$ ), and could thus not be used. The excited states character was analyzed for the $\mathrm{C}_{2} \mathrm{HO}_{3}{ }^{-}$ion by calculation of natural transition orbitals at the TDBHandHLYP level. ${ }^{47}$ Note that for calculation of excited states higher than $\mathrm{S}_{1}$ in $\mathrm{C}_{2} \mathrm{HO}_{3}{ }^{-}$, no diffuse functions were deliberately added; when diffuse functions are used, e.g. within the aug-ccpVXZ basis set series, pre-dissociation states start appearing below $5 \mathrm{eV}$ (at the B3LYP+D2/def2TZVP level of theory, the vertical ionization potential of $\mathrm{C}_{2} \mathrm{HO}_{3}{ }^{-}$in the gas phase is predicted to be $3.7 \mathrm{eV}$ ); these states disappear for glyoxylate in the salt environment. The shape of the $\mathrm{C}_{2} \mathrm{HO}_{3}{ }^{-}$absorption spectra was modeled using the linearized reflection principle approximation. ${ }^{48,49}$ Scans in the excited states were performed at the complete active space - self-consistent field (CASSCF) level of theory with the active space of $(6,6)$ and def2TZVP basis for $\mathrm{C}, \mathrm{O}, \mathrm{H}$ and the Stuttgart basis set ${ }^{50,51}$ for $\mathrm{Na}$ and $\mathrm{Cl}$ that do not participate in the excitation in order to speed up the calculations. Only two electronic states were included in the state average due to convergence issues when further lowlying excited states are treated. Multireference Configuration Interaction (MRCI) calculations with the same basis set were performed for structures optimized at the CASSCF level.

DFT and TDDFT calculations were done in the Gaussian software package, ${ }^{52}$ EOM-CCSD, CASSCF and MRCI calculations in the Molpro program. ${ }^{53}$

\section{Results and discussion}

\section{Photodissociation spectrum of $\left[\mathrm{Na}_{5} \mathrm{Cl}_{3}\left(\mathrm{C}_{2} \mathrm{HO}_{3}\right)\right]^{+}$in the range of 225-400 nm}

The photodissociation spectrum of the $\left[\mathrm{Na}_{5} \mathrm{Cl}_{3}\left(\mathrm{C}_{2} \mathrm{HO}_{3}\right)\right]^{+}$cluster was investigated experimentally in the range of $225-400 \mathrm{~nm}$. The measured photodissociation cross section for $\left[\mathrm{Na}_{5} \mathrm{Cl}_{3}\left(\mathrm{C}_{2} \mathrm{HO}_{3}\right)\right]^{+}$, including the contribution of the individual fragments, is shown in Fig. 1a. There is a strong absorption band at $230-250 \mathrm{~nm}$ with cross section on the order of $10^{-18} \mathrm{~cm}^{2}$, and a weaker band located at about $320-380 \mathrm{~nm}$ with cross sections below $10^{-19} \mathrm{~cm}^{2}$.

To gain further insight into the absorption spectrum, theoretical calculations of excited states for different isomers of the

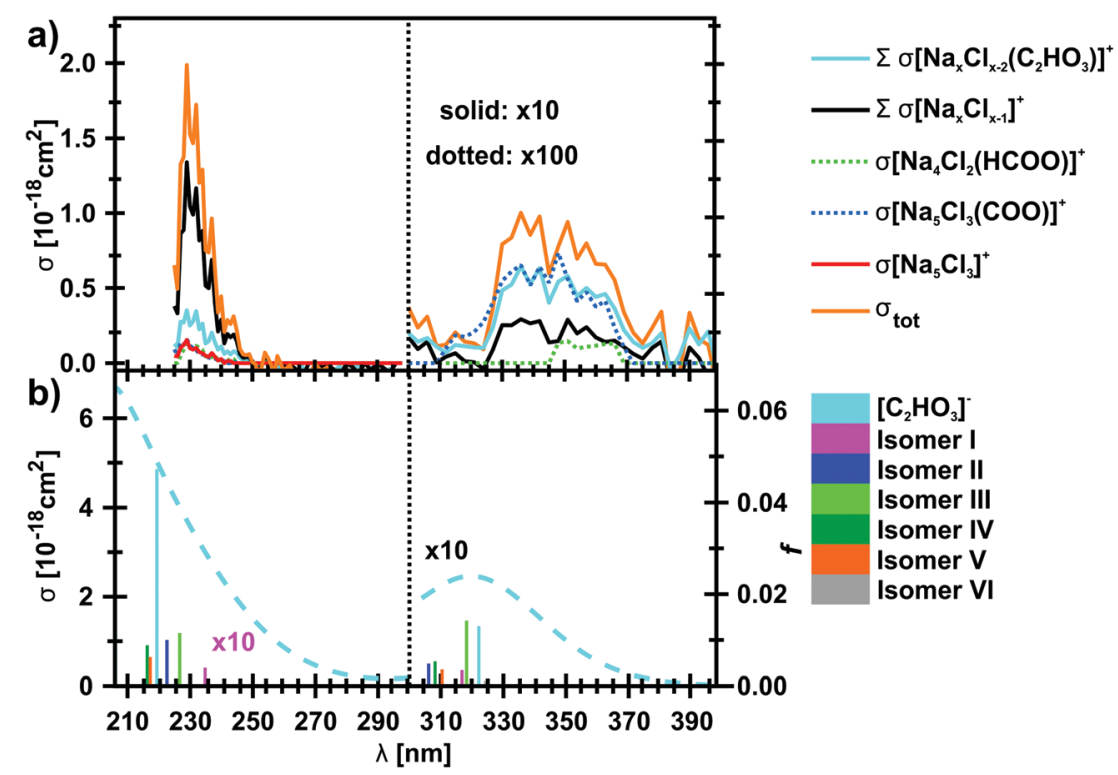

Fig. 1 (a) Measured total photodissociation cross section of the $\left[\mathrm{Na}_{5} \mathrm{Cl}_{3}\left(\mathrm{C}_{2} \mathrm{HO}_{3}\right)\right]^{+}$cluster as well as the contribution of specific fragments in the $225-400 \mathrm{~nm}$ range. In the range of 300-400 nm, only the contribution of the most intense fragments is shown. (b) Calculated excitation energies and oscillator strengths $f$ of $\mathrm{C}_{2} \mathrm{HO}_{3}^{-}$and several $\left[\mathrm{Na}_{5} \mathrm{Cl}_{3}\left(\mathrm{C}_{2} \mathrm{HO}_{3}\right)\right]^{+}$isomers (bars), modelled absorption spectrum of $\mathrm{C}_{2} \mathrm{HO}_{3}{ }^{-}$using the linearized reflection principle (dashed line). Calculated at the EOM-CCSD/cc-pVDZ//B3LYP+D2/def2TZVP level of theory. 
a)

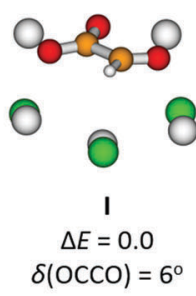

b)

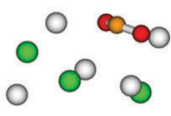

1
$\Delta E=0.0$
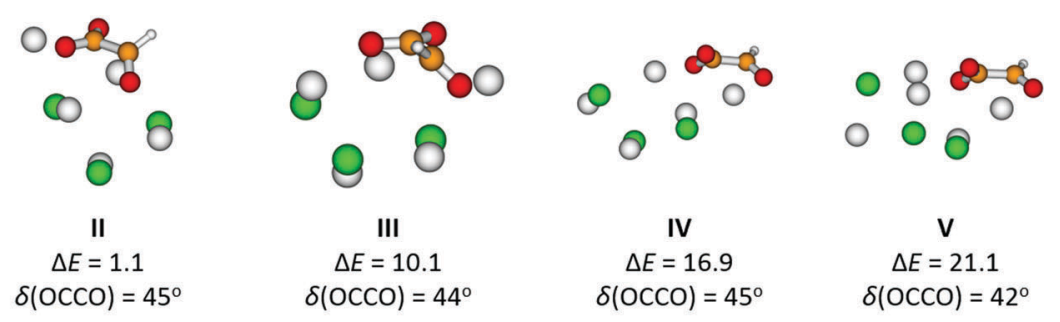

$\Delta E=21.1$

$\delta(\mathrm{OCCO})=42^{\circ}$

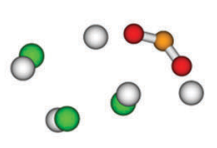

III
$\Delta E=5.3$

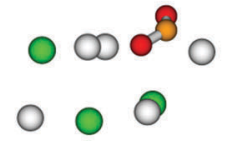

IV

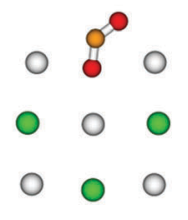

v

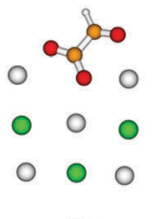

VI

$\Delta E=23.3$

$\delta(\mathrm{OCCO})=6^{\circ}$ c)

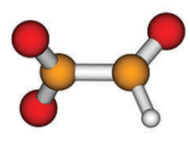

$\mathrm{C}_{2} \mathrm{HO}_{3}^{-}$ $\delta(\mathrm{OCCO})=70^{\circ}$

Fig. 2 Structures, relative energies $\Delta E$ (in kJ mol ${ }^{-1}$ ) and dihedral angles $\delta$ (in degrees) of selected isomers of (a) $\left[\mathrm{Na}_{5} \mathrm{Cl}_{3}\left(\mathrm{C}_{2} \mathrm{HOO}_{3}\right)\right]^{+}$and $(\mathrm{b})\left[\mathrm{Na}_{5} \mathrm{Cl}_{3}\left(\mathrm{CO}_{2}\right)\right]^{+}$; (c) $\mathrm{C}_{2} \mathrm{HO}_{3}^{-}$ion is shown for comparison. Calculated at the B3LYP+D2/def2TZVP level of theory.

cluster as well as for the isolated glyoxylate are shown in Fig. 1b, with the respective model systems provided in Fig. 2 and spectrum decomposition of two selected ions in Fig. 3 while scanning the $\mathrm{O}-\mathrm{C}-\mathrm{C}-\mathrm{O}$ dihedral angle. In the $\mathrm{C}_{2} \mathrm{HO}_{3}{ }^{-}$ion, the first absorption band is composed of only one transition of $\sigma_{2 \mathrm{p}, \mathrm{C}-\mathrm{C}} / \pi^{*} \mathrm{C}-\mathrm{O}$ character, while the second absorption band includes three different transitions of $n / \pi_{\mathrm{C}-\mathrm{C}}, \mathrm{n} / \pi^{*}{ }_{\mathrm{C}-\mathrm{O}}$ and $\sigma_{2 \mathrm{p}, \mathrm{C}-\mathrm{C}} / \pi^{*} \mathrm{CO}_{2}$ character, see orbitals in Fig. S3 (ESI $\dagger$ ). Both excitation wavelength and transition dipole moment show strong dependence on the $\mathrm{O}-\mathrm{C}-\mathrm{C}-\mathrm{O}$ dihedral angle $\delta$ (Fig. 3). In $\mathrm{C}_{2} \mathrm{HO}_{3}{ }^{-}$, there is a very low barrier for rotation along the dihedral angle, about $5 \mathrm{~kJ} \mathrm{~mol}^{-1}$ at the B3LYP+D2/def2TZVP level of theory, and a broad absorption spectrum can be expected. The width of the spectrum induced by the anharmonic effects, however, is neglected in the spectrum in Fig. 1 as it is simulated within the linearized reflection principle approximation.

For $\left[\mathrm{Na}_{5} \mathrm{Cl}_{3}\left(\mathrm{C}_{2} \mathrm{HO}_{3}\right)\right]^{+}$, calculations show that there are several isomers that lie close in energy (Fig. 2a), differing in position of the glyoxylate ion within the cluster and in the value of the $\mathrm{O}-\mathrm{C}-\mathrm{C}-\mathrm{O}$ dihedral angle. When the $\mathrm{C}_{2} \mathrm{HO}_{3}{ }^{-}$ion interacts with the salt cluster, there is a slight shift in the excitation energies and the movement along the $\mathrm{O}-\mathrm{C}-\mathrm{C}-\mathrm{O}$ angle becomes hindered as illustrated in the right-hand side of Fig. 3. For $\mathrm{C}_{2} \mathrm{HO}_{3}{ }^{-}$embedded in the cluster, we can thus expect hindered rotation along the $\mathrm{O}-\mathrm{C}-\mathrm{C}-\mathrm{O}$ dihedral angle and sharper bands in the absorption spectrum. However, only two absorption bands are still to be anticipated within the range of $200-400 \mathrm{~nm}$. The oscillator strength of the second electronic transition depends sensitively on the interaction of the glyoxylate chromophore with the ionic environment.

Electronic transitions of selected $\left[\mathrm{Na}_{5} \mathrm{Cl}_{3}\left(\mathrm{C}_{2} \mathrm{HO}_{3}\right)\right]^{+}$isomers are shown in Fig. 1b. The position of the first excited state in the $300-325 \mathrm{~nm}$ region is similar for all studied isomers while the relative intensity of the respective absorption band will be markedly affected by changes in the $\mathrm{O}-\mathrm{C}-\mathrm{C}-\mathrm{O}$ dihedral angle,

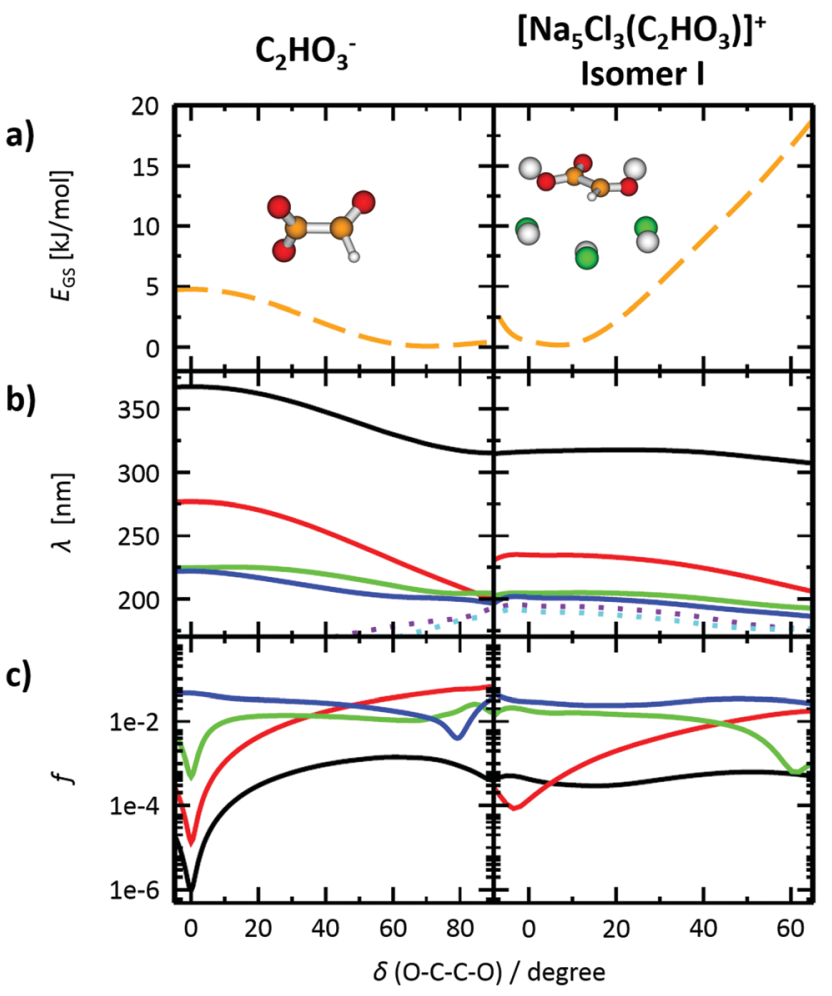

Fig. 3 Photochemistry of $\mathrm{C}_{2} \mathrm{HO}_{3}^{-}$and $\left[\mathrm{Na}_{5} \mathrm{Cl}_{3}\left(\mathrm{C}_{2} \mathrm{HO}_{3}\right)\right]^{+}$, isomer I. (a) Scan of the ground state energy $E_{G S}$ in dependence on the $\mathrm{O}-\mathrm{C}-\mathrm{C}-\mathrm{O}$ dihedral angle, calculated at the B3LYP+D2/def2TZVP level, with geometry fully optimized while constraining the dihedral angle value. (b) Excitation wavelengths $\lambda$ of four lowest excited states calculated in the structure corresponding to part (a) (solid lines). Two further higher lying excited states are shown for reference (dotted lines). Calculated at the EOM-CCSD/cc-pVDZ level of theory. (c) Oscillator strengths $f$ of the transitions shown in (b), employing the same color code for the electronic states. 
see Fig. 3. At lower wavelengths of $200-230 \mathrm{~nm}$, two groups of isomers can be distinguished with respect to their $\mathrm{O}-\mathrm{C}-\mathrm{C}-\mathrm{O}$ dihedral angle $\delta$, with the isomers with $\delta \sim 45^{\circ}$ (II-V) absorbing considerably more in the $210-230 \mathrm{~nm}$ region. Compared to the spectrum of $\mathrm{C}_{2} \mathrm{HO}_{3}{ }^{-}$, the intensity of the 220-240 $\mathrm{nm}$ absorption band is predicted to be markedly reduced, and a more structured spectrum can be expected.

The theoretical calculations reproduce the two absorption bands observed in the experiment. Quantitatively, the computationally predicted band positions are overestimated by about 0.2-0.3 eV. They are, however, very sensitive to the $\mathrm{O}-\mathrm{C}-\mathrm{C}-\mathrm{O}$ dihedral angle value and can therefore vary considerably when thermal effects are accounted for. Another possible explanation of the deviation is the neglect of the zero-point energy correction for dissociative processes that would shift excitation energies to lower values. ${ }^{54}$ With respect to the spectrum intensity, the calculated oscillator strengths amount to absolute cross sections of the same order of magnitude as observed in the experiment, $10^{-19} \mathrm{~cm}^{2}$ and $10^{-18} \mathrm{~cm}^{2}$ for first and second absorption band, respectively. The actual values, however, will be again considerably affected by isomer distribution and thermal effects.

\section{Photodissociation products of $\left[\mathrm{Na}_{5} \mathrm{Cl}_{3}\left(\mathrm{C}_{2} \mathrm{HO}_{3}\right)\right]^{+}$in the range of 225-400 $\mathrm{nm}$}

In Table 1, the observed photofragmentation channels (4)-(13) as well as the possible dissociation channels of the glyoxylate ion (1) and (2) are summarized together with the calculated dissociation energy. The dominant charged fragments are stoichiometric clusters, i.e. $\mathrm{Na}_{x} \mathrm{Cl}_{x-1}{ }^{+}$or $\mathrm{Na}_{x} \mathrm{Cl}_{x-2}\left(\mathrm{C}_{2} \mathrm{HO}_{3}\right)^{+}$. In the latter case, the glyoxylate moiety stays intact, and $\mathrm{Na}_{5-x} \mathrm{Cl}_{5-x}$ units are presumably lost. This implies the presence of a conical intersection ${ }^{5-57}$ between the ground state and the excited state(s) populated after excitation, which is required for internal conversion. At longer wavelengths, this is the preferred pathway, while at shorter wavelength, formation of $\mathrm{Na}_{x} \mathrm{Cl}_{x-1}{ }^{+}$ dominates. Again, stoichiometric $\mathrm{Na}_{5-x} \mathrm{Cl}_{4-x}\left(\mathrm{C}_{2} \mathrm{HO}_{3}\right)$ clusters may dissociate, reactions (5a)-(7a), but further decomposition into $\mathrm{Na}_{5-x} \mathrm{Cl}_{4-x}(\mathrm{HCOO})$ and $\mathrm{CO}$, reactions (5b)-(7b), is almost isoenergetic, and sometimes even energetically preferred. The latter scenario, however, requires photochemical rearrangements on the excited state potential energy surface. Strong evidence that this photochemical rearrangement is possible is provided by the $\mathrm{Na}_{x} \mathrm{Cl}_{x-2}(\mathrm{HCOO})^{+}$fragments, reactions (10)-(12), which are weak but unambiguously identified.

The final proof for excited state photochemistry is provided by the $\left[\mathrm{Na}_{5} \mathrm{Cl}_{3}\left(\mathrm{CO}_{2}\right)\right]^{\bullet+}$ fragment, a carbon dioxide anion radical embedded in the salt cluster produced in reaction (4), along with the elimination of the formyl radical $\mathrm{HCO}^{\bullet},{ }^{58}$ with a calculated reaction energy of $3.47 \mathrm{eV}$. For comparison, $\mathrm{CO}_{2}$ dissociation along reaction (3) is energetically more favorable with $2.43 \mathrm{eV}$, and might be expected to be a more efficient reaction channel in the ground state. This fragment, however, is not observed over the studied wavelength range. We note that the situation is similar for the photochemistry of the isolated glyoxylate anion, where the dissociation into $\mathrm{CO}_{2}{ }^{--}$and $\mathrm{HCO}^{\bullet}$ is $0.75 \mathrm{eV}$ higher in energy than the dissociation into $\mathrm{CO}_{2}$ and
Table 1 Reaction energies $\Delta E$ of various dissociation reactions of $\mathrm{C}_{2} \mathrm{HO}_{3}{ }^{-}$and $\left[\mathrm{Na}_{5} \mathrm{Cl}_{3}\left(\mathrm{C}_{2} \mathrm{HO}_{3}\right)\right]^{+}$ions calculated at the B3LYP+D2/def2TZVP level of theory. Reactions marked with ' $\star$ ' were calculated at the B3LYP+D2/def2TZVP//B3LYP+D2/6-31+g* level, with zero point energy corrections evaluated at the lower level of theory. The $\mathrm{C}_{2} \mathrm{HO}_{3}$ radical in reaction (13) is predicted to be unstable and dissociate into $\mathrm{CO}_{2}$ and $\mathrm{CHO}$. With the exception of reactions (1-3), all reactions included in the table were observed in our experiment

\begin{tabular}{|c|c|c|c|}
\hline No. & Reactant & Products & $\Delta E[\mathrm{eV}]$ \\
\hline (1) & $\mathrm{C}_{2} \mathrm{HO}_{3}{ }^{-}$ & $\mathrm{CHO}^{-}+\mathrm{CO}_{2}$ & 2.30 \\
\hline (2) & & $\mathrm{CO}_{2}^{\bullet-}+\mathrm{CHO}^{\bullet}$ & 3.05 \\
\hline (3) & {$\left[\mathrm{Na}_{5} \mathrm{Cl}_{3}\left(\mathrm{C}_{2} \mathrm{HO}_{3}\right)\right]^{+}$} & {$\left[\mathrm{Na}_{5} \mathrm{Cl}_{3}(\mathrm{CHO})\right]^{+}+\mathrm{CO}_{2}$} & 2.43 \\
\hline (4) & & {$\left[\mathrm{Na}_{5} \mathrm{Cl}_{3}\left(\mathrm{CO}_{2}\right)\right]^{0^{+}}+\mathrm{CHO}^{\bullet}$} & 3.47 \\
\hline (5a) & & $\mathrm{Na}_{2} \mathrm{Cl}^{+}+\mathrm{Na}_{3} \mathrm{Cl}_{2}\left(\mathrm{C}_{2} \mathrm{HO}_{3}\right)$ & 2.52 \\
\hline (5b) & & $\mathrm{Na}_{2} \mathrm{Cl}^{+}+\mathrm{Na}_{3} \mathrm{Cl}_{2} \mathrm{HCOO}+\mathrm{CO}$ & 2.69 \\
\hline (6a) & & $\mathrm{Na}_{3} \mathrm{Cl}_{2}^{+}+\mathrm{Na}_{2} \mathrm{Cl}\left(\mathrm{C}_{2} \mathrm{HO}_{3}\right)$ & 3.00 \\
\hline (6b) & & $\mathrm{Na}_{3} \mathrm{Cl}_{2}^{+}+\mathrm{Na}_{2} \mathrm{ClHCOO}+\mathrm{CO}$ & 3.01 \\
\hline (7a) & & $\mathrm{Na}_{4} \mathrm{Cl}_{3}^{+}+\mathrm{Na}\left(\mathrm{C}_{2} \mathrm{HO}_{3}\right)$ & 2.51 \\
\hline (7b) & & $\mathrm{Na}_{4} \mathrm{Cl}_{3}^{+}+\mathrm{NaHCOO}+\mathrm{CO}$ & 2.45 \\
\hline (8) & & {$\left[\mathrm{Na}_{2}\left(\mathrm{C}_{2} \mathrm{HO}_{3}\right)\right]^{+}+\mathrm{Na}_{3} \mathrm{Cl}_{3}$} & 2.48 \\
\hline (9) & & {$\left[\mathrm{Na}_{3} \mathrm{Cl}\left(\mathrm{C}_{2} \mathrm{HO}_{3}\right)\right]^{+}+\mathrm{Na}_{2} \mathrm{Cl}_{2}$} & 2.48 \\
\hline (10a) & & {$\left[\mathrm{Na}_{3} \mathrm{Cl}(\mathrm{HCOO})\right]^{+}+\mathrm{Na}_{2} \mathrm{Cl}_{2} \cdot \mathrm{CO}$} & 2.31 \\
\hline (10b) & & {$\left[\mathrm{Na}_{3} \mathrm{Cl}(\mathrm{HCOO})\right]^{+}+\mathrm{Na}_{2} \mathrm{Cl}_{2}+\mathrm{CO}$} & 2.48 \\
\hline (11a) & & {$\left[\mathrm{Na}_{4} \mathrm{Cl}_{2}(\mathrm{HCOO})\right]^{+}+\mathrm{NaCl} \cdot \mathrm{CO}$} & 2.21 \\
\hline (11b) & & {$\left[\mathrm{Na}_{4} \mathrm{Cl}_{2}(\mathrm{HCOO})\right]^{+}+\mathrm{NaCl}+\mathrm{CO}$} & 2.40 \\
\hline (12) & & {$\left[\mathrm{Na}_{5} \mathrm{Cl}_{3}(\mathrm{HCOO})\right]^{+}+\mathrm{CO}$} & 0.40 \\
\hline (13) & & {$\left[\mathrm{Na}_{5} \mathrm{Cl}_{3}\right]^{+}+\left[\mathrm{C}_{2} \mathrm{HO}_{3} \rightarrow \mathrm{CO}_{2}+\mathrm{CHO}\right]$} & 5.04 \\
\hline$(14)^{*}$ & {$\left[\mathrm{Na}_{6} \mathrm{Cl}_{4}\left(\mathrm{C}_{2} \mathrm{HO}_{3}\right)\right]^{+}$} & {$\left[\mathrm{Na}_{6} \mathrm{Cl}_{4}\left(\mathrm{CO}_{2}\right)\right]^{\bullet+}+\mathrm{CHO}^{\bullet}$} & 3.34 \\
\hline$(15)^{*}$ & {$\left[\mathrm{Na}_{7} \mathrm{Cl}_{5}\left(\mathrm{C}_{2} \mathrm{HO}_{3}\right)\right]^{+}$} & {$\left[\mathrm{Na}_{7} \mathrm{Cl}_{5}\left(\mathrm{CO}_{2}\right)\right]^{\bullet+}+\mathrm{CHO}^{\bullet}$} & 3.40 \\
\hline$(16)^{*}$ & {$\left[\mathrm{Na}_{8} \mathrm{Cl}_{6}\left(\mathrm{C}_{2} \mathrm{HO}_{3}\right)\right]^{+}$} & {$\left[\mathrm{Na}_{8} \mathrm{Cl}_{6}\left(\mathrm{CO}_{2}\right)\right]^{\bullet+}+\mathrm{CHO}^{\bullet}$} & 3.19 \\
\hline$(17)^{*}$ & {$\left[\mathrm{Na}_{9} \mathrm{Cl}_{7}\left(\mathrm{C}_{2} \mathrm{HO}_{3}\right)\right]^{+}$} & {$\left[\mathrm{Na}_{9} \mathrm{Cl}_{7}\left(\mathrm{CO}_{2}\right)\right]^{\bullet+}+\mathrm{CHO}^{\bullet}$} & 3.24 \\
\hline$(18)^{*}$ & {$\left[\mathrm{Na}_{10} \mathrm{Cl}_{8}\left(\mathrm{C}_{2} \mathrm{HO}_{3}\right)\right]^{+}$} & {$\left[\mathrm{Na}_{10} \mathrm{Cl}_{8}\left(\mathrm{CO}_{2}\right)\right]^{\bullet+}+\mathrm{CHO}^{\bullet}$} & 3.29 \\
\hline$(19)^{*}$ & {$\left[\mathrm{Na}_{11} \mathrm{Cl}_{9}\left(\mathrm{C}_{2} \mathrm{HO}_{3}\right)\right]^{+}$} & {$\left[\mathrm{Na}_{11} \mathrm{Cl}_{9}\left(\mathrm{CO}_{2}\right)\right]^{\bullet+}+\mathrm{CHO}^{\bullet}$} & 3.53 \\
\hline
\end{tabular}

$\mathrm{HCO}^{-}$, see reactions (1) and (2) in Table 1. Collision induced dissociation in the hexapole collision cell of the APEX Qe instrument confirms that, in the electronic ground state, the clusters dissociate by loss of stoichiometric cluster fragments, without $\mathrm{C}-\mathrm{C}$ bond cleavage.

Formation of $\mathrm{CO}_{2}{ }^{--}$embedded into the salt cluster involves breaking the $\mathrm{C}-\mathrm{C}$ bond of glyoxylate (see Fig. $2 \mathrm{~b}$ for calculated structures). The calculated reaction energy of equation (4) shows that the dissociation is plausible for the experimental wavelength range. This dissociation has also been observed in photochemical studies of isolated glyoxylic acid in the gas phase $^{26}$ or in aqueous solution. ${ }^{25}$ As noted above, excitation into $S_{1}$ involves the movement of an electron from $\sigma_{2 p} \rightarrow \pi^{*}$, causing the weakening of the $\mathrm{C}-\mathrm{C}$ bond, see Fig. S3 (ESI $\dagger$ ) for molecular orbitals of isolated glyoxylate.

\section{Photodissociation dynamics of $\left[\mathrm{Na}_{5} \mathrm{Cl}_{3}\left(\mathrm{C}_{2} \mathrm{HO}_{3}\right)\right]^{+}$in the first excited state}

To understand the photochemistry of glyoxylate and the influence of the salt environment in comparison with the neutral molecule, we studied photodissociation along the $\mathrm{C}-\mathrm{C}$ coordinate in the $\mathrm{S}_{1}$ state using methods of theoretical chemistry. Fig. 4 illustrates the results for the glyoxylate anion and the neutral glyoxylic acid molecule in the gas phase, compared with glyoxylate interacting with a sodium ion and embedded in the salt cluster. The latter comparison is crucial since the $\mathrm{NaC}_{2} \mathrm{HO}_{3}$ system can still be treated on the higher level of theory (here MRCI) while the 
$\mathrm{Na}_{5} \mathrm{Cl}_{3} \mathrm{C}_{2} \mathrm{HO}_{3}{ }^{+}$excited state is only tractable on the CASSCF level of theory. The excitation energy in the optimized ground state structure was added for reference.

When a glyoxylate ion in the gas phase is excited into $\mathrm{S}_{1}$ (Fig. 4a), it might reach a bound $S_{1}$ minimum. However, the photoexcited anion has enough excess energy to directly dissociate along the $\mathrm{C}-\mathrm{C}$ coordinate to form $\mathrm{CO}_{2}$ and $\mathrm{CHO}^{-*}$ in its first excited state. The alternative $\mathrm{CO}_{2}{ }^{--}+\mathrm{CHO}^{\bullet}$ dissociation channel lies higher in energy and becomes competitive only later along the dissociation coordinate, outside the region shown in Fig. 4a. Interestingly, there is no conical intersection, which renders internal conversion impossible for gas-phase glyoxylate within the investigated electronic states.

This picture changes dramatically when glyoxylate is protonated to form glyoxylic acid (Fig. 4b) or when it interacts with sodium ions (Fig. 4c and d). The photodissociation channel to produce $\mathrm{CHO}^{\bullet}$ and $\mathrm{CO}_{2}{ }^{--}$or $\mathrm{OCOH}^{\bullet}$ becomes preferred. This can be rationalized by the effect of the positive charge, either the proton or sodium ions in the salt cluster, that stabilizes the charge on the $\mathrm{CO}_{2}{ }^{--}$moiety. Along the reaction pathway, an $\mathrm{S}_{1} / \mathrm{S}_{0}$ conical intersection is reached at about $r_{\mathrm{C}-\mathrm{C}}=2.0 \AA$.

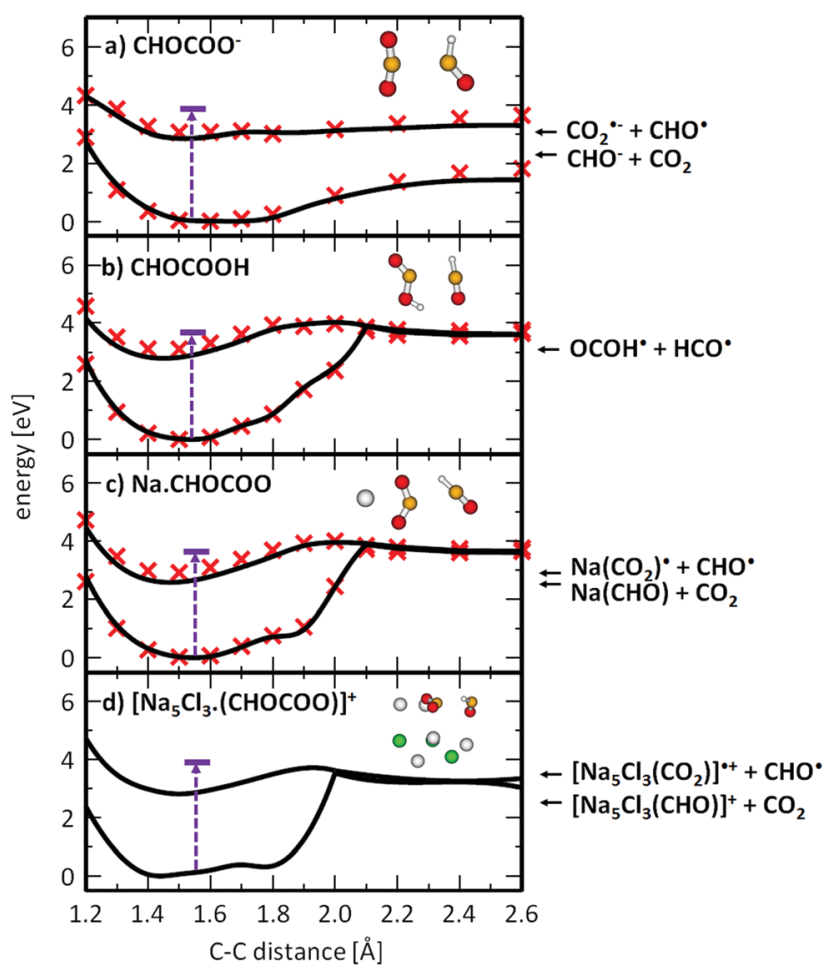

Fig. 4 Photodissociation of glyoxylate anion (a) and glyoxylic acid (b) in the gas phase and glyoxylate anion in the salt cluster environment (c and d). Structures were optimized in the $\mathrm{S}_{1}$ state along the $\mathrm{C}-\mathrm{C}$ dissociation coordinate at the CASSCF(6,6),SA2/def2-TZVP $(\mathrm{C}, \mathrm{H}, \mathrm{O})+\operatorname{Stuttgart}(\mathrm{Na}, \mathrm{Cl})$ level of theory (black lines) and recalculated at the respective $\mathrm{MRCl}$ level (red crosses). Excitation energy in the ground state minimum structure (in violet) was calculated at the EOM-CCSD/def2-TZVP $(\mathrm{C}, \mathrm{H}, \mathrm{O})+\operatorname{Stuttgart}(\mathrm{Na}, \mathrm{Cl})$ level in the structure optimized at the B3LYP+D2/def2-TZVP level, lying within $0.25 \mathrm{eV}$ with respect to $\mathrm{MRCl}$ values for (a)-(c). Energetics of the exit channels was calculated at the B3LYP+D2/def2-TZVP level (arrows on the right-hand side).
In the $\left[\mathrm{Na}_{5} \mathrm{Cl}_{3}\left(\mathrm{C}_{2} \mathrm{HO}_{3}\right)\right]^{+}$cluster, the CASSCF calculations predict that the energy provided by the excitation into the $\mathrm{S}_{1}$ state suffices to directly reach this intersection. After funneling into the electronic ground state in the vicinity of the conical intersection, the glyoxylate anion might further dissociate, be formed again in a vibrationally hot ground electronic state, or the dissociating $\mathrm{HCO}^{\bullet}$ radical may react with $\mathrm{CO}_{2}{ }^{--}$and transfer a hydrogen atom to form formate $\mathrm{HCO}_{2}{ }^{-}$and $\mathrm{CO}$. The barrier for such an $\mathrm{H}$ atom transfer in the ground state is calculated to be $1.93 \mathrm{eV}$ and $2.75 \mathrm{eV}$ for $\mathrm{C}_{2} \mathrm{HO}_{3}{ }^{-}$and $\mathrm{NaC}_{2} \mathrm{HO}_{3}$, respectively, at the $\mathrm{B} 3 \mathrm{LYP}+\mathrm{D} 2 / \mathrm{def} 2 \mathrm{TZVP}$ level of theory. Both values are significantly smaller than the initial excitation energy, thus formate formation is energetically accessible. Due to the momentum gained along the dissociation coordinate, the main channel can be expected to be $\mathrm{HOCO}^{\bullet}$ and $\mathrm{Na}^{+} \cdot \mathrm{CO}_{2}{ }^{\bullet-}$ formation for glyoxylic acid and $\mathrm{Na}\left(\mathrm{C}_{2} \mathrm{HO}_{3}\right)$, respectively. With the significantly larger number of degrees of freedom in $\mathrm{Na}_{5} \mathrm{Cl}_{3}\left(\mathrm{C}_{2} \mathrm{HO}_{3}\right)^{+}$, however, the probability for energy redistribution increases, and internal conversion reaching the original structure may prevail, followed by statistical dissociation from the electronic ground state. This would explain the dominance of the stoichiometric fragments $\mathrm{Na}_{x} \mathrm{Cl}_{x-2}\left(\mathrm{C}_{2} \mathrm{HO}_{3}\right)^{+}$and $\mathrm{Na}_{x} \mathrm{Cl}_{x-1}{ }^{+}$. It may be noted that this photochemical reaction pathway does not require a photocatalyst, as implied in earlier studies of adsorbed glyoxylate. $^{40-42}$

\section{The carbon dioxide radical anion and the $\mathrm{Na}_{5} \mathrm{Cl}_{3}{ }^{+}$fragment}

The most intriguing fragmentation channel is the dissociation of glyoxylate into the reactive $\mathrm{HCO}^{\bullet}$ radical and a carbon dioxide radical anion stabilized by the ionic environment of the salt cluster. ${ }^{59,60}$ In vacuum, the lifetime of $\mathrm{CO}_{2}{ }^{\bullet-}$ is only a few microseconds, because the free radical anion is metastable. ${ }^{61,62}$ However, interaction with the environment may stabilize $\mathrm{CO}_{2}{ }^{\bullet-}$, and it has been observed in liquid water, ${ }^{63}$ solvated by $\mathrm{CO}_{2}$ clusters $^{64}$ or water molecules ${ }^{65-70}$ in gas phase, as well as in low-temperature rare gas matrices ${ }^{71,72}$ or in room-temperature alkali halides like $\mathrm{NaBr}, \mathrm{KCl}, \mathrm{KBr}$, and $\mathrm{KI}^{.73,74}$ Due to the central role of $\mathrm{CO}_{2}{ }^{--}$as an intermediate in a future electrochemical utilization of carbon dioxide ${ }^{75}$ interest in the physicochemical properties of this elusive species has been rising steeply in the last decade. ${ }^{60}$ Our present results demonstrate that this fascinating radical anion is very likely also formed by natural processes in the troposphere.

It is important to note that the $\mathrm{CO}_{2}{ }^{\bullet-}$ fragment was found not only in the deeper UV in the wavelength range of 225-244 nm with no relevance for tropospheric chemical reactions (the corresponding light is completely absorbed in the stratosphere). The fragment was also measured in the actinic region of 310-370 $\mathrm{nm}$, i.e. at wavelengths that reach the ground and thus are able to induce photochemical reactions in the troposphere.

The $\left[\mathrm{Na}_{5} \mathrm{Cl}_{3}\right]^{\bullet^{+}}$fragment formed via reaction (13) is observed in the deeper UV up to $243 \mathrm{~nm}$. Its formation requires a charge transfer reaction from glyoxylate to the positive charge centers, i.e. one or more sodium ions. This charge transfer followed by release and decomposition of the $\mathrm{C}_{2} \mathrm{HO}_{3}{ }^{\bullet}$ radical is calculated 
to be $5.04 \mathrm{eV}$ endothermic. The $\mathrm{C}_{2} \mathrm{HO}_{3}{ }^{\bullet}$ radical is unstable and is predicted to dissociate into $\mathrm{CO}_{2}$ and $\mathrm{CHO}^{\bullet}$. This reaction may also proceed in two steps, i.e. $\mathrm{CHO}^{\bullet}$ dissociation followed by charge transfer with concomitant loss of $\mathrm{CO}_{2}$ from the intermediate $\mathrm{Na}_{5} \mathrm{Cl}_{3} \mathrm{CO}_{2}^{+}$cluster.

Photodissociation cross section of $\left[\mathrm{Na}_{n} \mathrm{Cl}_{n-2}\left(\mathrm{C}_{2} \mathrm{HO}_{3}\right)\right]^{+}, n=5-11$, in the range of 300-400 $\mathrm{nm}$

To examine if the results for the $\left[\mathrm{Na}_{5} \mathrm{Cl}_{3}\left(\mathrm{C}_{2} \mathrm{HO}_{3}\right)\right]^{+}$ion might be extrapolated to sea salt aerosols, we repeated the experiment with clusters containing up to 11 sodium ions. All studied clusters exhibit the $\alpha$-cleavage of the glyoxylate as a photodissociation channel, resulting in a sodium chloride cluster containing $\mathrm{CO}_{2}{ }^{\bullet-}$. Fig. 5 shows the total photodissociation cross section of the clusters with $n=5-9$ and the very small cross sections of the corresponding $\mathrm{CO}_{2}{ }^{--}$fragment down to $10^{-21} \mathrm{~cm}^{-2}$. The carbon dioxide anion fragments appear roughly in the wavelength range of $310-370 \mathrm{~nm}$, which corresponds to $4.00-3.35 \mathrm{eV}$, in agreement with theoretically calculated energies that predict nearly constant dissociation energy of 3.2-3.5 eV in the investigated cluster size range, see reactions (14)-(19) in Table 1 . For $n=5$, the quantum yield lies typically in the range of $5-10 \%$. The clusters with $n=6,11$ also show quantum yields up to $5.6 \%$ while the values for $n=7-10$ are between $1-3 \%$ (see also Fig. S4, ESI $\dagger$ ). This can be interpreted as competition of internal conversion with the $\mathrm{C}-\mathrm{C}$ bond cleavage, as already mentioned above. Internal conversion will be favored with an increasing number of degrees of freedom in the larger clusters. Fragments containing $\mathrm{HCOO}^{-}$that arise after a hydrogen transfer reaction are observed just above the noise level, with quantum yields of $1-3 \%$. However, they are definitely identified as a photodissociation channel that competes with simple $\mathrm{C}-\mathrm{C}$ bond cleavage. For clusters with $n=10,11$, the $\mathrm{CO}_{2}{ }^{--}$fragment was observed only for two wavelengths (see Fig. S5, ESI $\dagger$ ), due to the significantly increased noise level for the largest cluster sizes studied.

The measured photodissociation cross sections are used to estimate the photochemical lifetime of glyoxylate on the surface of sea-salt aerosols. Solar irradiance data was taken from terrestrial reference spectra for photovoltaic performance evaluation. $^{76,77}$ Convolution of the partial photodissociation cross section for formation of the $\mathrm{CO}_{2}{ }^{--}$and $\mathrm{HCOO}^{-}$containing product clusters from the $\left[\mathrm{Na}_{5} \mathrm{Cl}_{3}\left(\mathrm{C}_{2} \mathrm{HO}_{3}\right)\right]^{+}$experiment with the global tilt spectrum ${ }^{77}$ results in a photochemical lifetime of 13.6 $\mathrm{h}$ for glyoxylate in the sea-salt environment, much shorter than the aqueous phase lifetime of $5 \mathrm{~d}$ for reaction with $\mathrm{OH}^{\bullet}$ radicals estimated by Guzman and co-workers. ${ }^{25}$ Since photochemical aging of sea-salt aerosols takes place on a similar time scale, photolysis of the $\mathrm{C}-\mathrm{C}$ bond in glyoxylate may contribute to this process. However, under atmospheric conditions, glyoxylate may be present in its geminal diol form due to hydration. ${ }^{31}$ The study of hydration effects will be the next step towards a realistic modeling of glyoxylate photochemistry in the laboratory and by quantum chemistry.

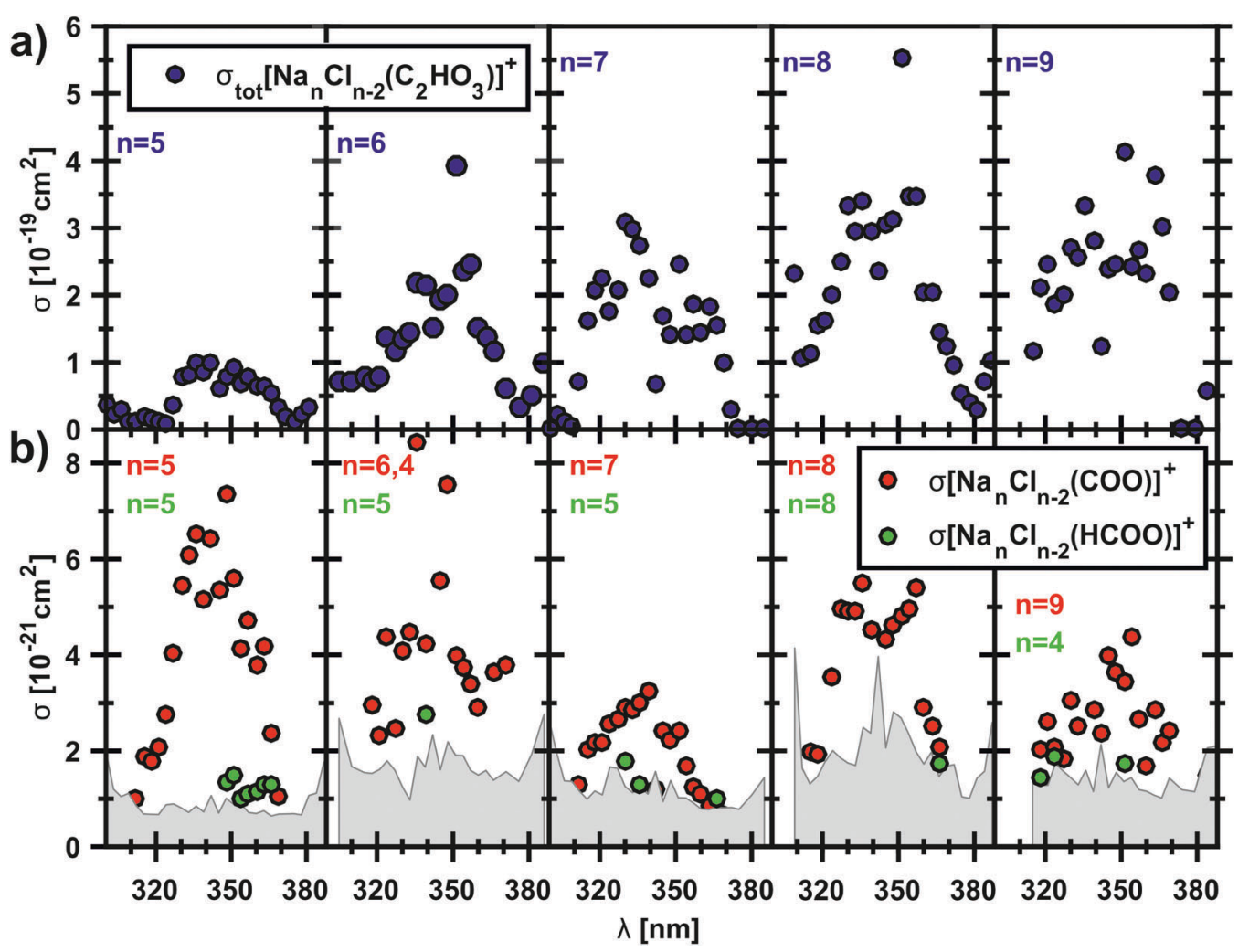

Fig. 5 Measured total photodissociation cross sections of the $\left[\mathrm{Na}_{n} \mathrm{Cl}_{n-2}\left(\mathrm{C}_{2} \mathrm{HO}_{3}\right)\right]^{+}$cluster, $n=5-9$, and the corresponding cross sections of the fragment with the carbon dioxide anion radical in the cluster. 


\section{Conclusions}

We investigated photodissociation of salt clusters doped with glyoxylate in the wavelength range of 225-400 $\mathrm{nm}$. Internal conversion of the excitation energy results in loss of stoichiometric cluster fragments $[\mathrm{NaCl}]_{x}$ or $\left[\mathrm{Na}_{x} \mathrm{Cl}_{x-1}\left(\mathrm{C}_{2} \mathrm{HO}_{3}\right)\right]$. A genuinely photochemical product is the carbon dioxide radical anion $\mathrm{CO}_{2}{ }^{--}$ embedded in the salt environment. This radical is produced by photolysis of the $\mathrm{C}-\mathrm{C}$ bond of glyoxylate, accompanied by the release of a neutral $\mathrm{HCO}^{\bullet}$ radical. The salt environment stabilizes $\mathrm{CO}_{2}{ }^{\bullet-}$. The radical anion was observed in the 300-400 $\mathrm{nm}$ wavelength range for all cluster sizes $\left[\mathrm{Na}_{n} \mathrm{Cl}_{n-2}\left(\mathrm{C}_{2} \mathrm{HO}_{3}\right)\right]^{+}, n=5-11$, suggesting that it is formed as a transient species in the troposphere. The photochemical lifetime calculated with typical solar irradiation data is in the range of $10 \mathrm{~h}$, which renders the photodissociation of glyoxylate a potentially relevant reaction in the photochemical aging of sea-salt aerosols. Excited state calculations reveal that $\mathrm{C}-\mathrm{C}$ bond cleavage takes places by surpassing a relatively small barrier along the excited state reaction coordinate and reaching the $\mathrm{S}_{1} / \mathrm{S}_{0}$ conical intersection. In the isolated glyoxylate anion in the gas phase, the $S_{0}$ and $S_{1}$ states are well separated, which prevents non-radiative relaxation to the electronic ground state. The electronic structure of gaseous neutral glyoxylic acid, however, is very similar to glyoxylate interacting with the salt environment. Repeating the calculations with $\mathrm{NaC}_{2} \mathrm{HO}_{3}$ reveals that the interaction of the deprotonated acid functional group with a single sodium ion is sufficient to restore the photochemical behavior of neutral glyoxylic acid.

\section{Conflicts of interest}

There are no conflicts to declare.

\section{Acknowledgements}

This work was supported by the Austrian Science Fund FWF within the DK-ALM: W1259-N27. M. O. acknowledges the support through the Lise Meitner Programme of the Austrian Science Fund (FWF) project No. M2001-NBL. The computational results presented have been achieved using the HPC infrastructure LEO of the University of Innsbruck.

\section{References}

1 C. D. O'Dowd and G. de Leeuw, Philos. Trans. A Math. Phys. Eng. Sci., 2007, 365, 1753.

2 B. J. Finlayson-Pitts and J. N. Pitts, Chemistry of the Upper and Lower Atmosphere. Theory, Experiments, and Applications, Academic Press, San Diego, 2000.

3 B. Gantt and N. Meskhidze, Atmos. Chem. Phys., 2013, 13, 3979.

4 B. J. Finlayson-Pitts, Chem. Rev., 2003, 103, 4801.

5 S. L. Mkoma and K. Kawamura, Atmos. Chem. Phys., 2013, 13, 2235.

6 K. Kawamura and S. Bikkina, Atmos. Res., 2016, 170, 140.

7 H. Tervahattu, J. Geophys. Res., 2002, 107, AAC1-1-AAC1-8.
8 J. Chen, K. Kawamura, C.-Q. Liu and P. Fu, Atmos. Environ., 2013, 67, 448.

9 A. Laskin, J. Laskin and S. A. Nizkorodov, Chem. Rev., 2015, 115, 4335.

10 T. Zielinski, Oceanologia, 1997, 39, 201.

11 A. K. Goroch, C. W. Fairall and K. L. Davidson, J. Appl. Meteorol., 1982, 21, 666.

12 C. D. O'Dowd, M. H. Smith, I. E. Consterdine and J. A. Lowe, Atmos. Environ., 1997, 31, 73.

13 M. Kanakidou, J. H. Seinfeld, S. N. Pandis, I. Barnes, F. J. Dentener, M. C. Facchini, R. van Dingenen, B. Ervens, A. Nenes, C. J. Nielsen, E. Swietlicki, J. P. Putaud, Y. Balkanski, S. Fuzzi, J. Horth, G. K. Moortgat, R. Winterhalter, C. E. L. Myhre, K. Tsigaridis, E. Vignati, E. G. Stephanou and J. Wilson, Atmos. Chem. Phys., 2005, 5, 1053.

14 U. Lohmann and J. Feichter, Atmos. Chem. Phys., 2005, 5, 715. 15 C. D. Papadimas, N. Hatzianastassiou, C. Matsoukas, M. Kanakidou, N. Mihalopoulos and I. Vardavas, Atmos. Chem. Phys., 2012, 12, 7165.

16 B. T. Johnson, K. P. Shine and P. M. Forster, Q. J. $R$. Meteorol. Soc., 2004, 130, 1407.

17 P. Beichert and B. J. Finlayson-Pitts, J. Phys. Chem., 1996, $100,15218$.

18 N. K. Richards and B. J. Finlayson-Pitts, Environ. Sci. Technol., 2012, 46, 10447.

19 C. George, M. Ammann, B. D’Anna, D. J. Donaldson and S. A. Nizkorodov, Chem. Rev., 2015, 115, 4218.

20 F. Bernard, R. Ciuraru, A. Boreave and C. George, Environ. Sci. Technol., 2016, 50, 8678.

21 X. Zhou, A. J. Davis, D. J. Kieber, W. C. Keene, J. R. Maben, H. Maring, E. E. Dahl, M. A. Izaguirre, R. Sander and L. Smoydzyn, Geophys. Res. Lett., 2008, 35, L20803.

22 C. Anastasio and J. T. Newberg, J. Geophys. Res., 2007, 112, 1153.

23 P. Dugourd, R. R. Hudgins and M. F. Jarrold, Chem. Phys. Lett., 1997, 267, 186.

24 J. A. Bradshaw, S. L. Gordon, A. J. Leavitt and R. L. Whetten, J. Phys. Chem. A, 2012, 116, 27.

25 A. J. Eugene, S.-S. Xia and M. I. Guzman, J. Phys. Chem. A, 2016, 120, 3817.

26 R. A. Back and S. Yamamoto, Can. J. Chem., 1985, 63, 542.

27 Y. B. Lim, H. Kim, J. Y. Kim and B. J. Turpin, Atmos. Chem. Phys., 2016, 16, 12631.

28 K. Kawamura, E. Tachibana, K. Okuzawa, S. G. Aggarwal, Y. Kanaya and Z. F. Wang, Atmos. Chem. Phys., 2013, 13, 8285.

29 P. Fu, K. Kawamura, K. Usukura and K. Miura, Mar. Chem., 2013, 148, 22.

30 S. Bikkina, K. Kawamura, Y. Miyazaki and P. Fu, Geophys. Res. Lett., 2014, 41, 3649.

31 H. Herrmann, T. Schaefer, A. Tilgner, S. A. Styler, C. Weller, M. Teich and T. Otto, Chem. Rev., 2015, 115, 4259.

32 C. W. Bock and R. L. Redington, J. Phys. Chem., 1988, 92, 1178.

33 C.-L. Lin and S.-Y. Chu, J. Am. Chem. Soc., 1999, 121, 4222.

34 K. L. Plath, J. L. Axson, G. C. Nelson, K. Takahashi, R. T. Skodje and V. Vaidaa, React. Kinet. Catal. Lett., 2009, 96, 209. 
35 K. Takahashi, K. L. Plath, J. L. Axson, G. C. Nelson, R. T. Skodje and V. Vaida, J. Chem. Phys., 2010, 132, 94305.

36 A. Olbert-Majkut, J. Lundell and M. Wierzejewska, J. Phys. Chem. A, 2014, 118, 350.

37 A. Mellouki and Y. Mu, J. Photochem. Photobiol., A, 2003, 157, 295.

38 A. E. Reed Harris, B. Ervens, R. K. Shoemaker, J. A. Kroll, R. J. Rapf, E. C. Griffith, A. Monod and V. Vaida, J. Phys. Chem. A, 2014, 118, 8505.

39 E. C. Griffith, B. K. Carpenter, R. K. Shoemaker and V. Vaida, Proc. Natl. Acad. Sci. U. S. A., 2013, 110, 11714.

40 E. R. Carraway, A. J. Hoffman and M. R. Hoffmann, Environ. Sci. Technol., 1994, 28, 786.

41 G. N. Ekström and A. J. McQuillan, J. Phys. Chem. B, 1999, 103, 10562.

42 C.-H. Ho, C.-Y. Shieh, C.-L. Tseng and J.-L. Lin, J. Phys. Chem. C, 2008, 112, 18134.

43 A. Herburger, C. van der Linde and M. K. Beyer, Phys. Chem. Chem. Phys., 2017, 19, 10786.

44 R. C. Dunbar, Mass Spectrom. Rev., 2004, 23, 127.

45 D. J. Wales, J. P. K. Doye, A. Dullweber, M. P. Hodges, F. Y. Naumkin F. Calvo, J. Hernández-Rojas and T. F. Middleton, The Cambridge Cluster Database, available at: http://wwwwales.ch.cam.ac.uk/CCD.html, accessed 6 June 2017.

46 S. Grimme, J. Comput. Chem., 2006, 27, 1787.

47 R. L. Martin, J. Chem. Phys., 2003, 118, 4775.

48 S. Y. Lee, R. C. Brown and E. J. Heller, J. Phys. Chem., 1983, 87, 2045.

49 M. Ončák, L. Šištík and P. Slavíček, J. Chem. Phys., 2010, 133, 174303.

50 P. Fuentealba, H. Preuss, H. Stoll and L. von Szentpály, Chem. Phys. Lett., 1982, 89, 418.

51 A. Bergner, M. Dolg, W. Küchle, H. Stoll and H. Preuß, Mol. Phys., 1993, 80, 1431.

52 M. J. Frisch, G. W. Trucks, H. B. Schlegel, G. E. Scuseria, M. A. Robb, J. R. Cheeseman, G. Scalmani, V. Barone, G. A. Petersson, H. Nakatsuji, X. Li, M. Caricato, A. Marenich, J. Bloino, B. G. Janesko, R. Gomperts, B. Mennucci, H. P. Hratchian, J. V. Ortiz, A. F. Izmaylov, J. L. Sonnenberg, D. Williams-Young, F. Ding, F. Lipparini, F. Egidi, J. Goings, B. Peng, A. Petrone, T. Henderson, D. Ranasinghe, V. G. Zakrzewski, J. Gao, N. Rega, G. Zheng, W. Liang, M. Hada, M. Ehara, K. Toyota, R. Fukuda, J. Hasegawa, M. Ishida, T. Nakajima, Y. Honda, O. Kitao, H. Nakai, T. Vreven, K. Throssell, J. A. Montgomery Jr, J. E. Peralta, F. Ogliaro, M. Bearpark, J. J. Heyd, E. Brothers, K. N. Kudin, V. N. Staroverov, T. Keith, R. Kobayashi, J. Normand, K. Raghavachari, A. Rendell, J. C. Burant, S. S. Iyengar, J. Tomasi, M. Cossi, J. M. Millam, M. Klene, C. Adamo, R. Cammi, J. W. Ochterski, R. L. Martin, K. Morokuma, O. Farkas, J. B. Foresman and D. J. Fox, Gaussian 09, Revision A.02, 2016.

53 H.-J. Werner, P. J. Knowles, G. Knizia, F. R. Manby, M. Schütz, P. Celani, T. Korona, R. Lindh, A. Mitrushenkov, G. Rauhut, K. R. Shamasundar, T. B. Adler, R. D. Amos, A. Bernhardsson,
A. Berning, D. L. Cooper, M. J. O. Deegan, A. J. Dobbyn, F. Eckert, E. Goll, C. Hampel, A. Hesselmann, G. Hetzer, T. Hrenar, G. Jansen, C. Köppl, Y. Liu, A. W. Lloyd, R. A. Mata, A. J. May, S. J. McNicholas, W. Meyer, M. E. Mura, A. Nicklass, D. P. O'Neill, P. Palmieri, D. Peng, K. Pflüger, R. Pitzer, M. Reiher, T. Shiozaki, H. Stoll, A. J. Stone, $\mathrm{R}$. Tarroni, T. Thorsteinsson and M. Wang, MOLPRO, version 2012.1, a package of ab initio programs, 2012.

54 M. K. Prakash, J. D. Weibel and R. A. Marcus, J. Geophys. Res., 2005, 110, 380.

55 W. Domcke and D. R. Yarkony, Annu. Rev. Phys. Chem., 2012, 63, 325 .

56 W. Domcke, H. Köppel and L. S. Cederbaum, Mol. Phys., 2006, 43, 851.

57 H. Köppel, L. S. Cederbaum and W. Domcke, J. Chem. Phys., 1982, 77, 2014.

58 R. Lesclaux, P. Roussel, B. Veyret and C. Pouchan, J. Am. Chem. Soc., 1986, 108, 3872.

59 D. Schröder, C. A. Schalley, J. N. Harvey and H. Schwarz, Int. J. Mass Spectrom., 1999, 185-187, 25.

60 J. M. Weber, Int. Rev. Phys. Chem., 2014, 33, 489.

61 R. N. Compton, P. W. Reinhardt and C. D. Cooper, J. Chem. Phys., 1975, 63, 3821.

62 M. Knapp, O. Echt, D. Kreisle, T. D. Märk and E. Recknagel, Chem. Phys. Lett., 1986, 126, 225.

63 I. Janik and G. N. R. Tripathi, J. Chem. Phys., 2016, 144, 154307.

64 S. Denifl, V. Vizcaino, T. D. Märk, E. Illenberger and P. Scheier, Phys. Chem. Chem. Phys., 2010, 12, 5219.

65 O. P. Balaj, C.-K. Siu, I. Balteanu, M. K. Beyer and V. E. Bondybey, Chem. - Eur. J., 2004, 10, 4822.

66 S. T. Arnold, R. A. Morris, A. A. Viggiano and M. A. Johnson, J. Phys. Chem., 1996, 100, 2900.

67 A. Akhgarnusch, W. K. Tang, H. Zhang, C.-K. Siu and M. K. Beyer, Phys. Chem. Chem. Phys., 2016, 18, 23528.

68 J. Lengyel, C. van der Linde, A. Akhgarnusch and M. K. Beyer, Int. J. Mass Spectrom., 2017, 418, 101.

69 T. Tsukuda and T. Nagata, J. Phys. Chem. A, 2003, 107, 8476.

70 R. F. Höckendorf, O. P. Balaj, C. van der Linde and M. K. Beyer, Phys. Chem. Chem. Phys., 2010, 12, 3772.

71 M. Zhou and L. Andrews, J. Chem. Phys., 1999, 110, 2414.

72 W. E. Thompson and M. E. Jacox, J. Chem. Phys., 1999, 111, 4487.

73 D. W. Ovenall and D. H. Whiffen, Mol. Phys., 1961, 4, 135. 74 K. O. Hartman and I. C. Hisatsune, J. Chem. Phys., 1966, 44, 1913.

75 C. G. Vayenas, R. E. White and M. Gamboa-Aldeco, Modern Aspects of Electrochemistry, Springer Science + Business Media, New York, 2008, vol. 42.

76 C. A. Gueymard, D. Myers and K. Emery, Sol. Energy, 2002, 73, 443.

77 National Renewable Energy Laboratory (NREL), Reference Solar Spectral Irradiance: Air Mass 1.5, available at: http:// rredc.nrel.gov/solar/spectra/am1.5/. 